\title{
1. The evolution of the separation of powers in the global south and global north
}

\section{David Landau and David Bilchitz}

The separation of powers has been a central tenet of constitutional design since the French Revolution and the design of the United States Constitution. Perhaps its most prominent defense has been that preventing the concentration of power in any one political institution would help to guard against the abuse of power. Indeed, this idea is one which has a long pedigree and analogues in many parts of the world.

While there was no developed doctrine of the separation of powers in pre-colonial African societies with much power concentrated in the hands of traditional leaders, such leaders were nevertheless required to consult with and seek the approval of advisory councils or popular assemblies (on matters of particular importance): this created opportunities by members of the community to check the power of the leader. ${ }^{1}$ Some of the theoretical foundations for the later development of the separation of powers doctrine in constitutional law were laid by Aristotle in Ancient Greece who recognized the desirability of a threefold division of power between a deliberative dimension, an executive dimension (he referred to this as the magistracy) and a judicial one. ${ }^{2}$

Whereas Aristotle focused on what would be an excellent form of government for the community, modern notions of the separation of powers developed during the Renaissance period, where the emphasis was placed firmly on how to ensure that power was not abused in a manner that severely circumscribed the liberty of individuals. Such ideas were initially put forward by John Locke ${ }^{3}$ and developed by Montesquieu, who argued for the necessity of distinguishing between a legislature (which made laws),

1 Tom Bennett and Christina Murray, Traditional Leaders, in ConstitutionaL LaW of South Africa 26 (Stuart Woolman ed., 2nd edn, 2006).

2 See Aristotle, Politics Book IV, chapter 14.

3 John Locke, Two Treatises of Government (1688). 
an executive (which implemented the laws), and a judiciary (which adjudicated disputes surrounding the laws). In giving expression to the central rationale for the separation of powers, Montesquieu famously stated that:

political liberty is to be found only in moderate governments; and even in these it is not always found. It is there only when there is no abuse of power: but constant experience shews us that every man invested with power is apt to abuse it, and to carry his authority as far as it will go ... To prevent this abuse, it is necessary, from the very nature of things, power should be a check to power. ${ }^{4}$

A particular structure of governance was thus developed to address concrete features of human nature (the tendency to abuse power) and also to advance particular substantive values such as liberty. This is an important point: in some jurisdictions, the separation of powers doctrine has often become an end in itself without having strong regard to the underpinning values and purposes that it is meant to realize.

Moving beyond the theoretical defenses of the idea occurred, for instance, when the real questions of institutional design were faced by the drafters of the United States Constitution. The drafters of the constitution recognized the importance of the division of powers as a starting point; but, it was also recognized that a differentiation of tasks was insufficient by itself to curb the abuse of powers. A central development occurred in the separation of powers idea with the introduction of the notion of "checks and balances:" each branch would not only have separate tasks but also powers needed to be granted to ensure that other branches were not exceeding their authority. ${ }^{5}$ An important advance in this vein took place when the United States Supreme Court recognized that it had the power of judicial review, which empowered the judiciary to strike down laws of parliament and actions of the executive which exceeded their authority or failed to comply with central constitutional values enshrined in the bill of rights. ${ }^{6}$

The goals and thinking behind the doctrine have proven to be so compelling that in virtually all democratic systems across the world, some version of the separation of powers concept has been enshrined in the constitution. In addition, there is a massive literature on the separation of powers, including recent attempts to reconceptualize traditional models. ${ }^{7}$

4 Charles Louis de Secondat, Baron de Montesquieu, The SpIRIT of the Laws (1748) Book XI Chap IV, in The Complete Works of M. De Montesquieu (1777).

5 See, e.g., The Federalist No. 51 (James Madison).

$6 \quad$ See Marbury v. Madison, 5 U.S. 137 (1803).

7 For some recent examples of this voluminous literature, see, for example, Matthew C. Stephenson, Does Separation of Powers Promote Stability and Moderation, 42 J. Leg. STUDS. 331 (2013) (challenging the assumption that 
This edited volume will aim to answer a set of questions that have remained relatively understudied: how should ideas about the separation of powers be rethought in light of an array of new problems that afflict predominantly "global south" contexts? How should courts and "fourth branch" institutions like human rights commissions and ombudsmen respond to the particular challenges - economic inequality, the dysfunction of political institutions, and the expansion of executive power - that arise in these contexts? How different are the answers to this question in the "global north" as opposed to the "global south"?

The contributors to this volume were motivated by a recognition of the value that the doctrine has but also by the need to re-think core aspects of the traditional model in light of recent changes both in design and practice. Much recent work has sought to develop new theoretical defenses or a reconceptualization of the purpose or functioning of the separation of powers. In contrast, this volume examines the evolution of the doctrine in light of important developments that we believe have been underexplored in existing work.

First, the recent past has seen important changes in the field of constitutional design. These trends are most pronounced in what Daniel Bonilla Maldonado has called the constitutions of the "global south," but they are far from exclusive to new or more fragile democracies. ${ }^{8}$ Newer constitutions tend to be much thicker documents, reflecting an alternative theory of constitutional design whereby constitutional drafters give detailed, and relatively flexible, instructions to political institutions. With increasing frequency, they contain rights such as socioeconomic and collective rights, and they may reflect "transformational" aspirations for their societies. These changes in design may all have significant implications for the manner in which the roles of courts and other institutions are conceived.

Further, many new constitutions also include a range of organs which do not fit into the traditional tripartite structure. South Africa, for instance, has created in Chapter 9 of its Constitution a public protector, a

the separation of powers promotes less legislation and more moderate legislation); Christoph Moellers, The Three Branches: A Comparative Model of SeParation OF POWERs (2013) (rethinking the separation of powers as a way of working out conflicts between individual liberty and democratic self-determination); Maxwell Cameron, Strong Constitutions - Social Cognitive Origins of the SEPARATION OF POWERs (2013) (arguing that the separation of powers is a way for constitutional states to use text to coordinate collective action).

8 See Daniel Bonilla Maldonado, Introduction: Towards a Constitutionalism of the Global South, in Constitutionalism of the Global South: The Activist Tribunals of India, South Africa, And Colombia 1 (2013). 
human rights commission, a commission for gender equality, a commission for the promotion and protection of the rights of cultural, religious and linguistic communities, an auditor-general, an electoral commission, and an independent authority to regulate broadcasting. ${ }^{9}$ This array of independent "checking" institutions is not unusual by comparative standards, and the ubiquitous nature of these independent accountability institutions problematizes the traditional tripartite division of powers.

One also notes important changes in the practice of the separation of powers. A series of political and technological changes have altered the way the traditional model functions. While these shifts are difficult to generalize across countries, scholars have noted an increase in executive power and a decrease in legislative legitimacy and importance. These shifts appear to be long-lasting and deeply rooted in changes in the nature of governance and the strength of political parties. They run across different regions and political contexts. More broadly, democratic institutions such as legislatures and party systems have been experiencing a loss in legitimacy and public trust throughout much of the world. In our view, scholarship has not adequately contended with the implications of these shifts - the growth of executive power and the crisis of legislative and democratic politics - for the classical model of the separation of powers. As several of the authors in this volume note, some courts seem to have responded by carving out an aggressive role conception, styling themselves as a check on executive power and a valid option for filling democratic deficits. Yet, the attractiveness of such a model across different contexts has not received sustained scholarly attention.

The rest of this chapter first introduces the major themes of this book by outlining each of these developments and their implications for the theory of the separation of powers. Secondly, it poses the question of whether the constitutionalism of the global south and global north have diverged on this topic, or whether a unified theoretical conception is possible. Finally, it provides a map of the chapters found in the book, exploring how they suggest answers to the questions posed in this chapter.

9 These institutions are commonly referred to - including in this volume - as Chapter 9 institutions, since they are included in Chapter 9 of the South African Constitution, titled "State Institutions Supporting Constitutional Democracy." See S.A. Const., arts 181-94 (1996). 


\section{CHANGES IN CONSTITUTIONAL DESIGN AND THE SEPARATION OF POWERS}

While constitutions written around the world respond in various ways to local concerns, they also reflect scripts that are responsive to broader global trends. Much recent empirical scholarship suggests that modern constitutionalism looks very different from the assumptions about constitutionalism at the time the separation of powers was invented. These changes have affected the length and density of constitutions, their content, and their basic institutional architecture.

\section{A. Thick and Flexible Constitutions}

First, the classical theory of constitutions envisions them as short, sparse and rigid documents. ${ }^{10}$ Some constitutions around the world, such as the United States federal constitution, fit this mold. Yet, as recent empirical work has shown, this framework model is increasingly uncommon. Instead, constitutions are often long and detailed documents. ${ }^{11}$ They regulate a broader variety of topics than their predecessors and treat these topics in more detail. Furthermore, they are often relatively flexible: at least many of their provisions can be amended without the extremely demanding standard found in the U.S. constitution. ${ }^{12}$

The causes of this change in the model of constitutional design have been explored by several scholars. Scheppele sees constitutional thickness as responding to a pervasive distrust of democratic institutions that is emblematic of, but hardly exhausted by, global south contexts. ${ }^{13}$ Thus, she argues that the new democracies in Eastern Europe opted for thicker constitutions as a way to restrain emerging democratic governments because they were uncertain about the intentions or capacity of newly

10 See Mila Versteeg and Emily Zackin, American Constitutional Exceptionalism Revisited, 81 U. CHI. L. REv. 1641, 1652-63 (2014) (showing that United States state constitutions, like most constitutions around the world, are far longer than the United States federal constitution).

11 See ibid.; Mila Versteeg and Emily Zackin, Constitutions Unentrenched: Towards an Alternative Theory of Constitutional Design, 110 Am. PoL. SCI. REv. 657 (2016) (presenting evidence showing that most constitutions around the world are both longer and more detailed, and easier to amend, than the United States federal constitution).

12 See Versteeg and Zackin, Constitutions Unentrenched, supra note 11.

13 See Kim Lane Scheppele, Democracy by Judiciary (or Why Courts can Sometimes be More Democratic than Parliaments), in Rethinking THE Rule of LAW AFTER COMMUnism 25, 31-6 (Wojciech Sadurski et al., eds, 2005). 
elected officials. ${ }^{14}$ Versteeg and Zackin see the model as an alternative form of constitutional design, and find traces of it in many comparative constitutions and in the constitutions of the U.S. states. ${ }^{15}$ They argue that drafters opt for thicker, more flexible constitutions as a way to control government by giving it detailed instructions that can be updated frequently. This is an alternative to framework constitutionalism, which seeks to limit government through the enunciation of framework norms that are made relatively durable and resistant to change. ${ }^{16}$

The impact of thick constitutionalism on the separation of powers has been underexplored in existing work. Take the judicial role as an example of this potential richness. On the one hand, thicker constitutions may change the ways in which constitutions are updated. Since they tend to be both more flexible and more in need of formal amendment, they may increase the frequency of amendment via formal channels and to some degree decrease the probability of judicial updating (through constitutional interpretation). ${ }^{17}$ On the other hand, thicker constitutions may increase the degree of oversight exercised by courts over the state by increasing the range of "constitutionalized" topics. In other words, in carrying out the impulses of constitutional design and democratic distrust that are argued to motivate the model, courts may end up accruing more power. Furthermore, courts working in systems with flexible amendment rules but in contexts where there are powerful and unrestrained executives or political forces may feel pressure to police the use of the constitutional amendment rule itself. This is consistent with evidence found by recent scholarship that the unconstitutional constitutional amendment doctrine, allowing courts to strike down attempted constitutional changes if they are inconsistent with the "basic structure" of the existing constitution (or for some similar reason) has proven to be one of the most successful recent exports in the field of comparative constitutional law. ${ }^{18}$ Many constitutions in fact now create this control in their constitutions textually, by creating multi-track systems of constitutional change where some

\footnotetext{
14 See ibid. at 37-8.

15 See Versteeg and Zackin, American Constitutional Exceptionalism Revisited, supra note 10, at 1703-705.

16 See ibid. (contrasting this model to an alternative in which constitutions are shorter, more rigid documents and arguing that the longer, more flexible model may be more democratic and less reliant on courts).

17 See Rosalind Dixon, Constitutional Amendment: A Comparative Perspective, in Comparative Constitutional Law 96, 97-8 (Tom Ginsburg and Rosalind Dixon, eds, 2011).

18 See Yaniv Roznai, Unconstitutional Constitutional Amendments: The Migration and Success of a Constitutional Idea, 61 Aм. J. ComP. L. 657 (2013).
} 
constitutional changes can be carried out relatively easily, while others require more demanding procedures. ${ }^{19}$ Courts and other actors working within flexible constitutions may sometimes become guardians of the constitutional text, thus allowing needed change while ensuring stability at the core. ${ }^{20}$

\section{B. More Expansive Rights Guarantees and Transformative Constitutionalism}

It has been well documented in empirical work that new constitutions contain an evolving list of rights. Classical civil and political rights of course remain constitutional staples, although their core content has shifted and expanded through time in response to changes in international and transnational discourse. ${ }^{21}$ These rights have, however, increasingly been joined in bills of rights by socioeconomic rights such as the right to housing and healthcare as well as collective rights like the right to the environment. Empirical work suggests that the number of rights found in constitutions has increased over time; perhaps, more significantly, so has their variation. ${ }^{22}$

Enforcement of socioeconomic and collective rights may put courts in positions that require more creative or aggressive assertions of judicial power. Effective enforcement of a socioeconomic right like the right to health will often require more than a simple order that the government refrain from taking a given action (although such negative enforcement remains of importance in the context of social rights too). Courts instead may need to require positive action on the part of the state, which could have budgetary implications or result in overseeing changes to

19 See, e.g., Richard Albert, Constitutional Handcuffs, 42 ARIz. ST. L.J. 663, 709-12 (2010) (giving examples).

20 See Rosalind Dixon and David Landau, Transnational Constitutionalism and a Limited Doctrine of Unconstitutional Constitutional Amendment, 13 INT'L J. Const. L. 606 (2015) (arguing that courts should use comparative evidence of transnational practice as one way to distinguish between core and non-core parts of their constitutions).

21 See Zachary Elkins, Tom Ginsburg and Beth Ann Simmons, Getting to Rights: Treaty Ratification, Constitutional Convergence, and Human Rights Practice, 54 HARV. INT'L L.J. 61 (2013) (demonstrating the influence of the International Covenant on Civil and Political Rights on inclusion of domestic constitutional rights).

22 See David S. Law and Mila Versteeg, The Evolution and Ideology of Global Constitutionalism, 99 CAL. L. REv. 1164, 1198 (finding a trend towards "rights creep," or an increased number of rights included in constitutions over time). 
government bureaucracies that allow for more successful social provisioning. ${ }^{23}$ Enforcement of rights which include a collective dimension, such as the right to water, perhaps raise even more significant challenges. Courts here may need to balance needs for individual provision or access against the collective dimension of the right, ensuring its sustainability and enjoyment by all and into the future. In enforcing these rights, as Bilchitz points out in this volume, considering the relationship between the right itself and the separation of powers may become particularly important. There is a temptation to bring separation of powers concerns into the very definition of the rights themselves, which muddles issues with very different normative underpinnings. Rigid doctrines of the separation of powers also may block courts from imposing orders requiring the spending of money or the construction of social programs, even if these would otherwise flow from a proper interpretation of the rights at issue. ${ }^{24}$

The expansion of rights is related to broader changes in the purpose of constitutional design. Karl Klare referred to the South African constitution of 1994 as a project of "transformative constitutionalism." 25 This conception stems from a number of features of the new constitution - its inclusion of a robust, expansive bill of rights, including social rights and a substantive approach to the right to equality, its recognition of duties upon private actors in relation to fundamental rights, and its focus on participatory and accountable institutions of governance. Yet, overarching all of this was the orientation of the constitution towards fundamentally

23 See Mark Tushnet, Weak Courts, Strong Rights: Judicial Review and Social Welfare Rights in Comparative Constitutional LaW 233-4 (2006).

24 See David Bilchitz, Poverty and Fundamental Rights: The Justification AND Enforcement of Socioeconomic Rights (2007) (arguing that the South African Constitutional Court's use of "reasonableness" review is designed to prevent the Court from overstepping what it sees as the provinces of other branches of government, but in the process prevents it from fully enforcing socioeconomic rights).

${ }_{25}$ See Karl E. Klare, Legal Culture and Transformative Constitutionalism, $14 \mathrm{~S}$. Afr. J. ON Hum. RTs. 146 (1998). The concept has spawned a substantial literature, particularly focused on South African constitutionalism. See, e.g., Dennis M. Davis and Karl Klare, Transformative Constitutionalism and the Common and Customary Law, 26 S. AFr. J. ON Hum. RTs. 403 (2010) (arguing that a formalistic and traditional legal culture is constraining the transformative project of the constitution, and thus that the project requires changes in legal and constitutional interpretation); James Fowkes, Transformative Constitutionalism and the Global South: The View from South Africa, in Transformative Constitutionalism in Latin America: A New Latin American Ius Commune (Arnim von Bogdandy et al., eds, 2017) (arguing that the insights of transformative constitutionalism in South Africa can be applied to Latin American constitutionalism). 
changing society - the South African constitution had to be understood as an instrument to transform the society from one in which there had been deliberately entrenched inequalities along primarily racial lines (but also which overlapped with gender, and socioeconomic status) to a society which gives expression to the foundational constitutional values of dignity, equality and freedom. ${ }^{26}$

Many constitutions of the "global south" have a significant transformative aspect in this sense - they do not simply preserve the status quo but commit the state to overcoming racial, ethnic, gender-based and economic inequalities in society. In Latin America, the constitutions of Colombia (discussed in Landau's chapter) and Brazil are good examples, as is the older Indian constitution. Yet, transformative constitutionalism is not exclusively a feature of the global south. Hailbronner, for example, has argued that the post-war German Basic Law also included a limited commitment to transformative constitutionalism, as a way to overcome the legacy of the Second World War. ${ }^{27}$

For our purposes, the key is to study the consequences of transformative constitutions for the separation of powers and especially for the judicial role. Since transformative constitutions require that steps be taken towards legal and social change, they may put additional pressure on the legislative and executive branches to adopt laws changing the status quo and to take steps to implement those laws effectively. If the political branches do not carry out these tasks or carry them out inadequately, it may fall to the judicial branch (as well as the other accountability institutions noted below) to carry out these projects partially or fully. Constitutional courts may also be charged with a range of other tasks that are relevant to projects of constitutional transformation, such as reworking the ordinary law in light of new constitutional standards. These are much more expansive tasks than had ordinarily been assigned to the judiciary, yet seem a legitimate exercise of judicial power in light of the expanded normative commitments and overarching purposes of many modern constitutions.

\section{New Accountability Institutions}

Finally, new constitutional texts tend to go well beyond the traditional tripartite division into the executive, legislative and judicial branches.

26 See Klare, supra note 25, at 151 (emphasizing that the South African constitution is "post-liberal" because it is "committed to large-scale, egalitarian social transformation").

27 See Michaela Hailbronner, Transformative Constitutionalism: Not Only in the Global South, 65 Aм. J. Comp. L. 527 (2017). 
To be sure, this division continues to exist, and in some ways has even strengthened through time. Courts, for example, almost always have explicit judicial review powers in modern constitutions, which was not always the case historically. ${ }^{28}$ However, modern constitutions also seem to depart from the premise that for the oversight of the modern state, courts are not sufficient. Thus, constitutions tend to include a number of other specialized accountability institutions. ${ }^{29}$ These often include electoral courts or commissions designed to ensure the integrity of the electoral process and human rights commissions, or ombudspersons designed proactively to investigate and rectify violations of the rights of individuals. They commonly also include a number of other independent actors like auditors, superintendents, procurators and others who are designed to monitor the state or particular areas of policy.

Existing academic work has often overlooked these institutions, and to date no unifying theory of their creation and functions seems to exist in the literature. ${ }^{30}$ Indeed, the impulse behind these institutions seems motivated by concerns connected with some of the foundational underpinnings of the separation of powers doctrine: namely, the idea that creating multiple nodes of power can more effectively help to check the abuse of power. It does not fall then to one institution - such as the judiciary - to ensure accountability with the Constitution, which may then find itself being undermined from within or subject to sustained forms of attack. The existence of constitutionalism that includes all of these new and independent institutions also seems to respond to one of the same impulses that lead to thicker constitutions: distrust of democratic actors and therefore an unwillingness to leave all oversight and policymaking to the legislature or a similar elected body. ${ }^{31}$ This approach may also reflect an increasing sense of the limitations of traditional courts or forms of judicial review, which tend to be largely reactive in nature. Investigation of widespread human rights violations, for example, may in some cases be better carried out by commissions rather than courts, because commissions are not dependent

28 See Law and Versteeg, supra note 22, at 1199 (noting that the percentage of constitutions having de jure or de facto judicial review has increased from $35 \%$ in 1946 to $87 \%$ by 2006 ).

29 See Kim Lane Scheppele, Parliamentary Supplements (or Why Democracies Need More than Parliaments), 89 B.U. L. REV. 795, 825 (2009).

30 However, some excellent studies exist. See, e.g., Ryan Goodman and Thomas Pegram, Human Rights, State Compliance, and Social Change: Assessing National Human Rights Institutions (2011) (presenting case studies of different human rights commissions and ombudspersons).

31 See Scheppele, supra note 29, at 824. 
upon cases being brought before them, may more easily range beyond individual cases, and might have better fact-finding capabilities. Moreover, on certain issues and in certain political contexts "advisory" decisions or recommendations made by non-judicial bodies may be more effective at advancing reform in a particular area than formal judicial decisions. ${ }^{32}$ The chapters in this volume do not purport to develop a unifying theory of nonjudicial accountability institutions, but they do give new insights into the tasks performed by these institutions, the ways in which they interact with judiciaries, and the conditions under which they can be effective.

\section{CHANGES IN THE PRACTICE OF THE SEPARATION OF POWERS}

Beyond changes in constitutional design, a number of changes in practice, created by technological, social and political shifts, have also had a significant impact on the separation of powers. We start by tracing shifts in the relative strength of the executive and legislative branches, and then explore the impact that a distrust of traditional political actors has had.

\section{A. The Expansion of Executive Power}

Concern about the scope of executive power is not new in comparative constitutional law - the constitutional history of certain regions, such as Latin America, is pervaded by a concern about this issue. ${ }^{33}$ Nonetheless, some recent trends have arguably created a shift in favor of executive power, while the legislative branch has arguably fallen into something of a constitutional crisis. The precise reasons for these shifts vary from country to country, but the trend as a whole seems widespread, running for example across presidential, parliamentary and semi-presidential systems. ${ }^{34}$ Without seeking to be exhaustive, we mention some of those factors here.

32 See Christopher S. Elmendorf, Advisory Counterparts to Constitutional Courts, 56 Duke L.J. 953, 957 (2007) (arguing that these institutions may be in a better position than Constitutional Courts to carry out some democracyreinforcing tasks because they may be more capable of adopting "legislative solutions" and because they are more "dialogic" in nature).

33 See Miguel Schor, Constitutionalism Through the Looking Glass of Latin America, 41 TEX. INT'L L.J. 1, 3 (2006) (noting the history of caudillo presidents with dictatorial powers in the region).

34 Of course, the dynamics of the separation of powers vary between types of systems. For example, the executive and legislative branches have independent sources of electoral authority and fixed terms in a presidential system, while they are 
First, of course, technological and social factors have greatly increased the density of regulations and the frequency with which they are changed. This has necessitated a growth in administrative states, meaning that legislatures delegate more power to executives, often through broad statutory frameworks that allow administrative officials to do much of the policymaking. ${ }^{35}$ Related to this is of course the speed with which each branch is capable of acting. The deliberative nature of a legislature may be an increasingly uncomfortable fit for the fast pace with which legal change needs to take place in the modern world.

Beyond these well-known and very long-term factors, some commentators have argued that changes in the international environment have also strengthened the executive branch and weakened the legislature. For example, some scholars of the European Union have pointed out that the technocratic orientation of that body has systematically tended to shift power towards executive officials, who gain a privileged position in the effort to comply with an increasingly dense network of supranational regulations. ${ }^{36}$ More generally, as the amount of policymaking occurring at the international level has increased, the executive branch may tend to be in a more powerful position to formulate and implement these processes.

Changes in geopolitics heighten these patterns. Scheppele, for example, has tracked the influence of terrorism-related rhetoric on the separation of powers. She finds that new mandates at the international level have also tended to increase the power of the executive branch by requiring and empowering executive branch officials to carry out a number of different tasks, many with a high degree of secrecy and speed. ${ }^{37}$ There are also many examples where the executive branch in countries around the world has utilized the rhetoric of terrorism as a way to increase

mutually dependent in parliamentarism. See, e.g., Jenny S. Martinez, Horizontal Structuring, in The OxFord Handbook of Comparative Constitutional Law 547, 553 (Michel Rosenfeld and Andras Sajo, eds, 2012). But see Richard Albert, The Fusion of Presidentialism and Parliamentarism, 57 AM. J. CoMP. L. 531, 564-5 (2009) (noting that under common conditions and designs, parliamentarism can replicate a separation between the executive and legislative branches found in presidentialism). We gloss over these differences here and focus on which branch of government exercises policymaking authority.

35 See Martinez, supra note 34, at 563-4.

36 See, e.g., Lisa L. Martin, Democratic Commitments: Legislatures AND INTERNATIONAL COOPERATION 150-51 (2000).

37 See Kim Lane Scheppele, The Migration of Anti-Constitutional Ideas: The Post-9/11 Globalization of Public Law and the International State of Emergency, in The Migration of Constitutional Ideas 347, 368 (Sujit Choudhry, ed., 2007). 
their power, justifying maneuvers that would otherwise be suspect on the grounds of the separation of powers or the protection of individual rights. ${ }^{38}$ Conditions of economic crisis, like the sharp global downturn beginning in 2008, may also contribute to these trends. The European Union's responses to these crises, for example, may have further shifted the balance between the executive and the legislature in member states by largely relying on a model of technocratic, emergency policymaking and negotiation rather than democratic deliberation. ${ }^{39}$

In many countries pathologies in party systems exacerbate these shifts in power. These pathologies largely, but not entirely, afflict newer democracies, or what Issacharoff refers to as fragile democracies that are in danger of experiencing democratic erosion. ${ }^{40}$ Many but by no means all of these pathologies are found in the global south. In many countries across the world, a dominant party controls all or most of the institutions of government. ${ }^{41}$ Although there may be reasonably free elections, this party faces no significant competition and is not in great danger of losing power in the near future. It is thus able to control all the levers of power and reduce the effectiveness of checks and balances in the system. Such a system places obvious pressures on the separation of powers. In particular, it may allow essentially for the fusion of what are supposed to be distinct branches within the separation of powers, with the executive at its head, as well as the reduction in importance of subnational governments in federalism-like arrangements (which are also controlled by the dominant party). ${ }^{42}$ The legislature, judiciary and other independent checking institutions may all be unwilling or unable to check an executive at the head of a dominant-party system, as they are often packed with appointees sympathetic to the dominant party. ${ }^{43}$

The executive branch may also exercise heightened political power in situations where political parties are very weak or deinstitutionalized,

38 See ibid. at 368.

39 See, e.g., Deidre Curtin, Challenging Executive Dominance in European Democracy, Amsterdam Centre for European Law and Governance Working Paper Series 2013-09 (December 2013), at http://www.acelg.uva.nl/publications

40 See Samuel Issacharoff, Fragile Democracies (2015).

$41 \quad$ See ibid. at 255.

42 See Sujit Choudhry, "He Had a Mandate": The South African Constitutional Court and the African National Congress in a Dominant Party Democracy, 2 Const. CT. Rev. 1 (2009).

43 See, e.g., Ozan O. Varol, Lucia Dalla Pellegrina and Nuno Garoupa, An Empirical Analysis of Judicial Transformation in Turkey, 65 Aм. J. CoмP. L. 187 (2017) (presenting evidence showing that judicial reforms carried out by a dominant party in Turkey reduced judicial independence). 
which is also a fairly common pathology in many parts of the world. ${ }^{44}$ Without cohesive political parties, legislatures may lack the capacity and willingness to take a significant role in national policymaking. ${ }^{45}$ The links between executive and legislative officials may be weaker, encouraging executives to govern around legislatures by using decree power and other means, rather than by seeking to advance policy agendas in legislative institutions. ${ }^{46}$

For the purposes of this volume, a key issue is how these interconnected factors ought to impact upon a theory of the separation of powers. One possibility, of course, is that they heighten the need for judiciaries and other independent accountability institutions. Excessive concentration of executive power may lead to less democratic policymaking, as well as potentially heightening the risk posed to minority groups and individual rights. Some of the chapters in this volume suggest that an imbalanced executive power may justify heightened efforts by courts or other actors to formulate policy and to check executive policymaking. ${ }^{47}$ Landau, for example, argues that courts can aim, at least in modest ways, to ameliorate defects in party systems and improve the functioning of political institutions through time.

At the same time, some authors suggest caution with respect to the idea that such a role will or should emerge. Jackson, for instance, argues that while executive power has increased in the United States, efforts by the Supreme Court to rebalance the separation of powers have sometimes borne too little fruit relative to the expenditure of judicial capital, and the Court might be better off not intervening on some questions. In a similar vein, recent developments in Hungary have increased the need for a powerful judicial branch, but some of the very dynamics tending to increase this need - the rise of a populist and potentially dominant party that rewrote the constitution to increase its own power - have tended to

44 See Scott Mainwaring and Timothy R. Scully, Introduction: Party Systems in Latin America, in Building Democratic Institutions: Party Systems in LATin America 1, 4-6 (Scott Mainwaring and Timothy R. Scully, eds, 1995) (defining the concept of an "institutionalized" party system with roots in society, versus an inchoate party system without such roots).

45 See David Landau, Political Institutions and Judicial Role in Comparative Constitutional Law, 51 HaRv. INT'L L.J. 319, 330-32.

46 See Mainwaring and Scully, supra note 44, at 26. This is not of course the only pathology produced by weak party systems. An alternative possibility is that "outsider" executives, especially in presidential systems, will be unable to govern at all, producing frequent governability crises. See ibid.

47 See Issacharoff, supra note 40 (arguing that courts may be well positioned to check pathologies created in dominant-party systems). 
undermine rather than increase judicial power. These examples thus raise questions about the limits of judicial ability to ameliorate broad shifts in power towards the executive. ${ }^{48}$ Uitz's chapter in this volume suggests a kind of guarded optimism on this question, especially when the judiciary seeks to empower other institutions rather than shouldering the burden of restraining the executive themselves.

\section{B. Decreases in the Centrality and Legitimacy of Democratic Institutions}

A second cluster of problems concerns changes in the centrality of and trust in democratic institutions. These trends again appear to be broadranging and the product of a number of factors which vary in type and intensity across different countries.

A number of developments have tended to reduce the centrality of the role played by national governmental institutions across many countries. In some regions, such as the European Union, much policymaking power has been transferred to the international realm. ${ }^{49}$ More broadly, and as has long been argued, globalization may increase the importance of institutions other than the nation-state, such as corporations, while reducing the ability of the nation-state to protect its own citizens. ${ }^{50}$

Trends in public trust in both political institutions (legislatures; executives; courts) and the institutions surrounding those bodies (political parties; the media) are somewhat less clear, but they do suggest a crisis of confidence in political institutions across large swaths of both the developing world and mature democracies. In contexts where corruption is very high, such as across much of the developing world, evidence suggests that this sharply reduces public trust in government. In countries with endemic corruption, citizens often do not believe that political institutions are serving their interests. ${ }^{51}$ Even without high levels of corruption, confidence in public institutions may decline because of economic stagnation or

48 See, e.g., Tom Gerald Daly, The Alchemists: Questioning Our Faith IN Courts as Democracy-Builders (2017) (arguing that prevailing theories and institutions have placed too much weight on courts for stabilizing and building transitional democracies).

49 See Martin, supra note 36.

50 See, e.g., Kenichi Ohmae, The End of the Nation State (1995). Parts of this thesis, of course, have proven extremely controversial, and recently some authors have argued that the simple globalization story underestimates the resilience and continuing importance of traditional governmental institutions. See, e.g., Dani Rodrik, Who Needs the Nation-State?, 89 Econ. Geo. 1 (2012).

51 On the other hand, low levels of trust also appear to be a cause of corruption, creating something of a vicious cycle. See Stephen D. Morris and Joseph 
other factors. Thus the economic crisis of 2008 appears to have been associated with declines in trust in governmental institutions across much of the global north. ${ }^{52}$ Similar trends are being found in the global south: for instance, a recent survey of the attitudes of individuals in the most populous province of South Africa (Gauteng) found that only $40 \%$ of respondents thought that parliament represented them and over $60 \%$ found it difficult to access democratic institutions. ${ }^{53}$

These interlocking trends create a number of problems for the separation of powers that may not be fully dealt with in traditional theory. For example, there has been an increase in the power that private entities such as corporations exercise and their ability to influence the public political space through lobbying and utilizing their economic wealth to advance their political ends. Governmental institutions must now clearly determine the public/private line. ${ }^{54}$ An overly formalistic understanding of the separation of powers may hamper courts and other actors from fully responding to the threat posed by the privatization of public power. The very conception of what constitutes the domain of public power is facing renewed challenge: a recent case in South Africa dealing with the payment of social grants to 17 million South Africans was forced to consider the status of a private entity which was contracted to perform these payments by the executive branch of the government. The Constitutional Court found that, for the purposes of paying these grants, the company was in fact an organ of state, which implied that it now had obligations sourced in constitutional law rather than simply contract law. ${ }^{55}$

Moreover, the growth of private power also raises questions as to whether the separation of powers doctrine needs to be extended in some

L. Klesner, Corruption and Trust: Theoretical Considerations and Evidence from Mexico, 43 Comp. Pol. STuds. 1258 (2010).

52 See Felix Roth, Felicitas Nowak-Lehmann D., and Thomas Otter, Has the Financial Crisis Shattered Citizens' Trust in National and European Governmental Institutions? Evidence from the EU Member States, 1999-2010, CEPS Working Document No. 343 (June 2011), at https://www.ceps.eu/system/files/book/2011/02/ WD $\% 20343 \% 20$ Roth $\% 20$ et $\% 20$ al $\% 20$ on $\% 20$ trust.pdf.

53 The survey was conducted by the South African Institute for Advanced Constitutional, Public, Human Rights and International Law, a centre of the University of Johannesburg, as part of a project commissioned by the International Institute for Democracy and Electoral Assistance on the Performance of the South African Constitution. The overall report is available at http://www.constitution net.org/vl/item/assessing-performance-south-african-constitution.

54 Professor Surya Deva presented a paper on this topic at the event which served as the catalyst for this book.

55 See Allpay Consolidated Investment Holdings v. Chief Executive Officer of the South African Social Security Agency 2014 (4) SA 179 (CC) paras 54-60. 
way beyond the public sphere alone. Indeed, as was discussed above, its core driving force of preventing the overconcentration of power is applicable within private entities - in relation to their governance and in relation to their activities - where they become overly powerful through monopolistic control over particular domains such as the provision of pharmaceutical drugs. Some constitutions in the global south, for instance, such as that of South Africa, have recognized that private entities, even when they are not exercising a public power, have direct obligations that flow from fundamental rights. ${ }^{56} \mathrm{~A}$ full understanding of the impact of such developments on private parties themselves, as well as the general conception of the separation of powers doctrine more generally, is worthy of further research.

A further consequence of the loss of legitimacy of institutions like political parties is that in some countries it has changed the nature of the actors gaining political power. "Outsider" or even "anti-system" actors and political parties are often more likely to be able to win political power in environments where there is little public trust in traditional political institutions. These sorts of "outsider" political leaders have long been prevalent in parts of the global south, for example in Latin America, and more recently similar movements have swept to power in places like Hungary and Poland. Recent events, such as the election of Donald Trump in the United States and the increasing power of such outsider movements in Western Europe, suggest that this phenomenon may be spreading to more mature democracies. The meaning of these outsider movements varies from place to place, but, in general, they may exert new pressures on the separation of powers. Political actors and movements of this type may be more willing to undermine the independence and relevance of other institutions, particularly those such as courts that are intended as a horizontal check on their power. ${ }^{57}$ These actors and movements may adopt a stance that privileges their direct connection with voters while de-emphasizing

56 See section 8(2) of the South African Constitution which reads: 'a provision of the Bill of Rights binds a natural or a juristic person if, and to the extent that, it is applicable, taking into account the nature of the right and the nature of any duty imposed by the right'.

57 See Guillermo A. O’Donnell, Delegative Democracy, 5 J. Democ. 55 (1994) (arguing that some recent Latin American experiences suggest a model of democracy in which leaders poorly linked to existing parties seek to govern by relying on vertical accountability from voters and de-emphasizing or ignoring horizontal accountability from other political institutions). Donald Trump has also launched attacks on judges and the courts when he has lost cases: see, for instance, J. Rosen, 'Not even Andrew Jackson Went as Far as Trump in Attacking the Courts' The Atlantic (Feb 9, 2017) available at https://www.theatlantic.com/politics/ 
the importance of other institutions of government whose functions may need to be exercised in a less populist manner.

Constitutional design and practice have been slow to adjust to these changes, but they do suggest partial responses to some of these trends. From the standpoint of design, as already noted, many recent constitutional orders suggest that courts alone are not enough. Instead, judiciaries are joined by a number of other independent institutions. Many of these, such as electoral commissions, independent prosecutors and anti-corruption commissions, are intended to police the integrity of the electoral realm. ${ }^{58}$ Courts themselves, in some systems particularly found in the global south, have become what Robinson has recently called "good governance courts." 59 These judiciaries have responded to weaknesses in the political order by taking on an activist stance, seeking to root out political corruption and helping to address other key problems such as socioeconomic inequality that are left unanswered by the political sphere. In the extreme, they use doctrines such as the unconstitutional constitutional amendment doctrine to protect against proposed constitutional changes that threaten to undermine the democratic order. In brief, these courts use pervasive levels of political distrust as a justification for taking on a more aggressive and activist conception of the judicial role. ${ }^{60}$

\section{A GLOBAL SOUTH THEORY OF THE SEPARATION OF POWERS?}

A major question treated by a number of chapters in this book is whether there are differences in the way the separation of powers should be theorized in the "global south" and "global north." Doctrines of the separation of powers were historically constructed, as Bonilla's chapter reminds us, in a particular historical context. Recent work in comparative constitutional law has argued that the field has de-emphasized the experiences of "global south" countries. ${ }^{61}$ Indeed, inequalities between global north and global south countries have also translated into dynamics surrounding

archive/2017/02/a-historical-precedent-for-trumps-attack-on-judges/516144/ (last accessed 26 March 2017).

58 See supra text accompanying notes 28-32.

59 See Nick Robinson, Expanding Judiciaries: India and the Rise of the Good Governance Court, 8 Wash. U. Global STUd. L. Rev. 1 (2009) (referring to the Indian Supreme Court as a paradigm example of such a trend).

60 See ibid.; see also Landau, supra note 45.

61 See Bonilla Maldonado, supra note 8. 
the valuation of knowledge in these contexts. Unjustifiable assumptions have suggested that the best knowledge emanates from the north, which is automatically afforded respect whereas that in the global south is generally perceived as weak and as dependent upon approval by the north for its legitimation. ${ }^{62}$ These dynamics have in fact often led even courts in the global south to reference and implement doctrines that are not clearly applicable in their contexts.

Whilst there is no doubt validity in the global south critique, it has not yet clearly succeeded in identifying what is distinctive about global south constitutionalism, beyond identifying a list of topics - such as socioeconomic rights, access to justice, and indigenous rights - that may be particularly pressing in those contexts, but not unique to them. Hirschl, for example, expresses sympathy with the point that the field of comparative constitutional law has focused on the experiences of only a very small, potentially non-representative group of countries, but he also argues that the global south critique has failed to explain what exactly is distinctive about its model of constitutionalism. ${ }^{63}$

Many of the chapters in this book suggest that theories of the separation of powers and the judicial role specifically may be one fruitful place to seek a theory of global south constitutionalism. In general, these chapters suggest that traditional conceptions of the separation of powers may be less applicable in the global south, potentially leading to more flexible and aggressive conceptions of the judicial role and that of other bodies. In part, this is because of the distinctive challenges that tend to be faced by these constitutional systems.

For example, while many constitutions now include socioeconomic rights, the challenges that these pose are likely to be considerably greater in developing contexts than in wealthier, more mature democracies. In wealthier democracies, fairly-developed social welfare nets are likely to exist, and most residents are likely to enjoy at least a minimum level of access to goods such as housing, food and healthcare. In developing democracies, these assumptions do not, generally, hold - a large number of residents may be deprived of enjoyment of even the most basic of essential socioeconomic rights, welfare nets may be patchy and designed to include only relatively privileged formal-sector workers while excluding the most marginalized, and delivery systems and bureaucracies may be

62 For an examination of these assumptions and inequalities, see Daniel Bonilla Maldonado, Legal Clinics in the Global North and South: Between Equality and Subordination - An Essay, 16 Yale Hum. RTS. \& Dev. L.J. 176, 185-90 (2013).

63 See Ran Hirschl, Comparative Matters (2014). 
systematically flawed in not being able to provide even benefits that are legally prescribed. ${ }^{64}$

Thus, while socioeconomic rights are now a part of global constitutionalism, they are central to the constitutionalism of the global south. The enforcement of socioeconomic rights may additionally place far greater tensions on traditional conceptions of the separation of powers and the judicial role in these contexts, since courts will need to issue orders not only to correct relatively minor defects and omissions in the social welfare system, but also to prod the state towards constructing entirely new programs and correcting large-scale omissions and bureaucratic dysfunctions. Courts may also need to be creative in their remedies in order to address the lack of capacity that branches of the executive exhibit: thus, supervisory orders and appointing managers to ensure implementation are not always part of the judicial role as traditionally conceived but may be entirely justifiable in light of the constitutional design and socio-political conditions in certain global south countries. ${ }^{65}$ If, as Bilchitz's chapter argues, the relationship between rights and the separation of powers is a key issue when enforcing socioeconomic rights, then this issue should have particular bite in the global south.

The flaws in the separation of powers explored in this volume may also be particularly salient in global south contexts. These political systems may be particularly prone to flaws in their party systems, producing for example a single dominant party or non-institutionalized parties rather than political competition between multiple strong parties. ${ }^{66}$ These systems may also be particularly prone to executive aggrandizement and to the risks posed by outsiders who win office and then seek to undertake projects of democratic erosion. Finally, they may be particularly likely to experience pervasive levels of corruption and higher levels of political distrust.

Thus, it may be no accident that activist "good governance courts" have sprung up in global south contexts such as India and Colombia,

64 See, e.g., Javier Couso, The Changing Role of Law and Courts in Latin America: From an Obstacle to Social Change to a Tool of Social Equity, in CourTS and Social Transformation in New Democracies: An Institutional Voice FOR THE PoOR? 61, 73 (Roberto Gargarella, Pilar Domingo and Theunis Roux, eds, 2006).

65 See, e.g., the multiple orders given by the Supreme Court of India in the famous right to food case PUCL v. Union of India, Civil Writ Petition 196 of 2001 available at http://www.righttofoodcampaign.in/legal-action/supreme-court-orders

66 See Issacharoff, supra note 40 (constructing an argument for strong judicial interventions to protect the democratic order in transitional and new democracies). 
in contexts of overarching political distrust. ${ }^{67}$ These courts have deemphasized traditional conceptions of the separation of powers in order to seek to ameliorate problems of political corruption, overcome entrenched social inequalities, and control processes of constitutional change against risks to the democratic order. As Landau argues in this volume, they arguably disregard some of the classical constraints of the separation of powers in order to realize substantive projects of constitutional realization or to improve the functioning of political institutions themselves.

Finally, the independent accountability institutions explored in this volume have become a part of constitutional design across a range of democratic orders, but they may be particularly salient in global south contexts. In Mexico, for example, these institutions - like the Supreme Court itself - have played a key role in the country's transition away from a one-party state. ${ }^{68}$ In South Africa and other fragile democratic states in Africa, these institutions are often called upon to play a crucial accountability function in checking still-extant dominant parties. ${ }^{69}$ They can play roles such as ensuring the integrity of elections, reducing endemic corruption, and overseeing the behavior of the executive, in contexts where other institutions are unwilling or unable to play these roles.

Yet as the chapters of Mahomed, Kapindu and Serna point out, independent accountability institutions working in these contexts, and their designers, also often face particularly difficult challenges. They may face threats to their independence or weakly-defined roles that render more complex the task of negotiating space from other institutions like courts. On the flip side, in contexts where institutions are weak, these institutions themselves may face a lack of accountability for their job performance. In sum, a climate of political distrust and dysfunction increases the needs for and burdens on these independent accountability institutions, but it also may make it more difficult for them to succeed.

These differences, we emphasize, are ones of degree, not of kind. All of the trends we have surveyed in this chapter reach well beyond the global

67 See supra text accompanying notes 59-60; see also Bonilla Maldonado, supra note 8 .

68 For example, the Electoral Tribunal, created during the transition process, has played an important role in protecting the integrity of Mexican elections. See, e.g., Steven T. Wuhs, Savage Democracy: Institutional Change and Party Development in Mexico 144-6 (2008) (recounting the role of the electoral tribunal after a disputed election in Mexico in 2006).

69 See Charles M. Fombad, The Role of Emerging Hybrid Institutions of Accountability in the Separation of Powers, in SEPARATION OF Powers IN AFrican Constitutionalism 359 (Charles M. Fombad, ed., 2016). 
south, even if they are most pronounced in those contexts. Socioeconomic rights, thick constitutions and the rise of independent accountability institutions are truly global phenomena in constitutional design. So too are increases in executive power, decreases in legislative power and legitimacy, and crises in the legitimacy and centrality of political institutions. As Jackson's chapter shows, for example, courts in the United States have long wrestled with, and mostly accommodated, sweeping changes in the separation of powers that have greatly increased executive power. Thus, an examination of positive and normative changes in the global south may tell us something about shifts in the separation of powers more broadly.

The chapters in this volume thus constitute a set of considerations that could form the basis for a revised theory of the separation of powers in comparative constitutional law, even if they are particularly applicable to global south contexts. Indeed, it is important that global constitutional theory be receptive to influences from the developments in the south rather than simply reflect currents in the global north. Most of the chapters, for example, suggest the inadequacy of formalistic doctrines of the separation of powers in light of the shifts surveyed here. ${ }^{70}$ Pre-existing conceptions of the "proper" judicial role, for example, are insufficient to fully realize newer forms of rights such as socioeconomic rights or to maintain balances in the separation of powers in the context of certain forms of political dysfunction. Courts and other bodies that wield these doctrines unthinkingly may thus be abdicating their constitutional responsibilities rather than fulfilling them. Indeed, arguably, some judges under the guise of an inapplicable notion of the separation of powers actually do harm to the constitutional rights, for instance, they are meant to adjudicate. This does not mean, of course, that the principles underlying the separation of powers have no bite, or that there should be few or no limits on judicial power. It does mean, however, that the limits on the judicial role and the power of other bodies like independent accountability institutions should be tested, rather than being taken as a given. The impetus for the separation of powers doctrine - preventing the overconcentration of power - is as relevant today as it has always been: but, the exact contours of the doctrine need to be rethought in light of the changed constitutional design and circumstances we have sought to articulate.

70 This general account has some resonance with a long-standing "formalist" versus "functionalist" divide in the U.S. separation of powers literature. See, e.g., William N. Eskridge, Jr., Relationships between Formalism and Functionalism in Separation of Powers Cases, 22 Harv. J. L. \& Pub. PoL'y 21 (1998-1999). 


\section{THE PLAN OF THIS VOLUME}

The rest of the chapters in this volume build their arguments on the statement of themes presented in this chapter. The genesis of this book was a two-day event of the International Association of Constitutional Law held at the South African Constitutional Court and the University of Johannesburg in Johannesburg, South Africa. This event was organized by the South African Institute for Advanced Constitutional, Public, Human Rights and International Law (SAIFAC), a centre of the University of Johannesburg, and sponsored by Konrad Adenauer Stiftung in May 2015. A selection of the papers presented there are included in this volume.

Part I of this book focuses on broad themes in the evolution of the separation of powers in the global south and the global north, in response to some of the circumstances outlined in this chapter. It focuses on distinctive problems in these contexts and considers the extent to which they necessitate rethinking the ideas surrounding the separation of powers. This also enables us to reflect on the extent to which there is in fact a distinctive global-south approach to the separation of powers or whether the theories and problems explored here have a more universal scope.

Chapter 2, by David Landau, argues that some "global south" courts are building a new conception of the judicial role in response to poorly functioning political institutions. Drawing primarily on the jurisprudence of the Colombian Constitutional Court, he argues that these theories might properly be labelled "intertemporal" - they relax some of the ordinary constraints on judicial action in the interest of positively impacting upon the constitutional and political system over time. His chapter explores two kinds of "intertemporal" theories. In the first, a court takes on some of the responsibilities of other branches of government in contexts where other institutions have neglected those projects, in order to advance core goals of constitutional transformation. In the second, a court seeks to improve the performance of political institutions and the political system through time. Landau's chapter thus suggests that a distinctive constitutionalism of the global south can in part be built around theories of the judicial role that arise from political distrust and dysfunction.

Chapter 3, by David Bilchitz, focuses on an important question that arises once courts are given the task of interpreting and enforcing socioeconomic rights, as is increasingly the case in global south contexts particularly. Bilchitz notes that courts often raise issues of the separation of powers (such as the institutional capacity and legitimacy of the different branches of government) in the course of interpreting socioeconomic 
rights, and they use these considerations as a way to deny or limit relief. The "reasonableness" approach of the South African Constitutional Court, for example, has often placed institutional considerations at the core of the interpretation of rights such as housing and healthcare. Bilchitz argues that this approach is conceptually and normatively inappropriate as it conflates questions which have an entirely distinct normative foundation. When interpreting constitutional rights, courts should first interpret the substantive scope of the entitlement to which a claimant is entitled. Only once the scope of the right has been defined should courts consider whether institutional issues provide any reasons to modify the practical obligations that flow from these rights. Bilchitz thus argues for an approach to enforcing socioeconomic rights that does not ignore the separation of powers, but which distinguishes these issues from the interpretation of the right itself. It would thus discourage courts from using the separation of powers to avoid fully engaging with socioeconomic rights.

Renata Uitz's contribution, in Chapter 4, focuses on the extent to which courts can check a rise in executive power, especially but not exclusively in newer democracies such as those found in Africa, Eastern Europe and Latin America. She develops a typology of the different contexts in which judicial interventions have occurred and argues that courts can often intervene to check executive power in ways that are consistent with their conceptions of the role of and practical constraints on judicial power. She also suggests, based on a number of examples, that courts are more likely to be successful at carrying out this function when their jurisprudence serves to empower other institutions to counterbalance the executive, rather than simply blocking the executive directly. Her argument suggests room for optimism even under fairly difficult circumstances, provided that judges are willing to think creatively about their roles in the political order.

Chapter 5, by Vicki Jackson, considers the shifts that have taken place in the separation of powers doctrine in an "old" constitutional system, namely that of the United States. Jackson notes that the U.S. separation of powers has developed significantly through time; for example, the executive branch has grown sharply in size and power. Yet she also argues that the Supreme Court has played only a relatively minor role in shaping these shifts; its main role has been to accommodate rather than challenge these changes. When the Court has been more active in policing the separation of powers, she finds, it is often hard to tell whether it has corrected or contributed to political dysfunction. Jackson's chapter thus holds both lessons and cautions for courts of the global south. Her case study suggests that older constitutional orders are dealing with some of the same pressures as newer ones, and the United States may offer a model for how courts can respond to changes in the separation of powers over time. 
At the same time, her analysis suggests uncertainty that courts can actually correct for political dysfunctions.

In Chapter 6, Daniel Bonilla Maldonado attempts to reconstruct the underlying conceptual architecture of the separation of powers. His chapter explores the subjects of the separation of powers - both state and individual - the notion of time constructed by the principle, and the concept of space within which it operates. His careful conceptual analysis suggests that the separation of powers has universalistic, timeless pretensions as a fundamental principle of constitutional governance. At the same time, it unsettles these universalistic pretensions by showing the particular ways in which the separation of powers structures the temporal rhythm of social change and assumes a cosmopolitan international order composed of liberal democracies. Bonilla thus raises the question of how the model of the separation of powers meshes with quintessentially global south concerns like the achievement of social justice. Implicitly, he poses the basic question underlying this entire volume: whether and how the classical model of the separation of powers can be rethought to respond to shifts in both constitutional design and practice.

Part II moves from more general theory to a focus on a particular set of independent accountability institutions that are a major feature of contemporary constitutional design. These chapters point out both the promise of these institutions in increasing accountability and transparency in new democracies, but also the struggles they often face in carving out appropriate roles in those contexts. The focus on this particular set of institutions is helpful in attempting to think through how they engender a shift in the traditional conception of the separation of powers.

Chapter 7, by Faraaz Mahomed, takes a close look at South Africa's independent "Chapter 9" Institutions, such as the Public Protector, the Electoral Commission and the Human Rights Commission. He considers whether these institutions in fact form a "fourth" branch which is distinct from the traditional three branches in the separation of powers doctrine. He argues that these institutions enhance the rationale for the separation of powers doctrine in preventing the overconcentration of power but that they should be conceived as a distinctive branch of government. Their focus is centrally on promoting accountability through non-coercive means and providing proactive opportunities to advance the vision of the new constitutional order through non-adversarial processes of dispute resolution as well as research, advocacy, constitutional interpretation and inputs into policy processes. Whilst the performance of these functions fundamentally enhances the quality of governance, the ability of these institutions to do their work is imperiled by a lack of resources and attempts to undermine them by other branches of government. 
Responding to these challenges identified by Mahomed may well help advance the separation of powers doctrine further in requiring the articulation of further checks and balances on the traditional three branches to ensure the 'fourth branch' is given adequate space and opportunity to exercise its functions.

Chapter 8, by Redson Kapindu, carries out a case study of the Malawi Human Rights Commission. Like Mahomed, Kapindu argues that independent accountability institutions can potentially play a key role in ensuring good governance and accountability in weakly institutionalized environments. He also argues that these are institutions "sui generis" and thus appears to agree with Mahomed's characterization that they could constitute a fourth branch of government. Kapindu finds that the Human Rights Commission has played a role in serving as a check on the executive and in developing the content of international human rights and constitutional values within Malawi. Kapindu argues generally that while the Commission has at times had difficulty carving out an independent role from the executive branch, it has nonetheless claimed significant accomplishments within a challenging political context. He also makes the important argument that revising the conception of these independent accountability institutions can have an impact on the concrete doctrines that courts adopt in relation to them. Thus, recognizing the unique role of human rights commissions should, in his view, lead the Malawian courts to adopt a wider doctrine of standing for the human rights commission to intervene in matters that affect fundamental rights.

In Chapter 9, José Ma. Serna de la Garza looks at the role of the Mexican Commission on Human Rights. Serna argues that there is a great need for institutions promoting the enjoyment of and governmental accountability for human rights in the Mexican context, but that the Commission has largely fallen short of its potential. Serna argues that the problems with the Commission are in part a product of a poorly defined conception of its role, particularly in its relationship with the Supreme Court. More fundamentally, Serna argues that the Commission's poor performance is caused more by a lack of accountability than a lack of independence: no other institution has adequate supervisory authority to ensure that the Commission carries out its task well. Serna's argument thus highlights the complex task faced by constitutional designers in addressing the architecture of these new institutions, who must ensure an adequate balance between independence and accountability. 


\section{CONCLUSION: THE RELEVANCE AND EVOLUTION OF THE SEPARATION OF POWERS}

This chapter has sought to outline the normative origins of the separation of powers and to chart some of the forces which are placing pressure on the traditional conception thereof. The doctrine has never remained static and has evolved even in the jurisdictions, such as the United States and France, where it was initially developed. Its adoption in most of the constitutions that have been formed in recent times - particularly in countries of the global south - requires detailed thinking about how it needs to evolve to achieve its own normative goals but also those - such as the socioeconomic rights of individuals - which have become more pressing in modern times. Utilizing an inappropriate form of the separation of powers doctrine for particular circumstances can in fact undermine constitutionalism through inhibiting the possibilities of creative legal responses to complex institutional and political dynamics. Doing so can in extreme cases ultimately harm political stability and lead to violence being seen as the only option for change.

The challenge of adapting and developing the separation of powers doctrine is not one that can be achieved within the course of one book. However, we hope that the chapters in this volume pose a number of important questions and potential answers which can provide a catalyst for further research and reaching the next stage in the evolution of the separation of powers doctrine. 
David Landau and David Bilchitz - 9781785369773 Downloaded from PubFactory at $04 / 26 / 2023$ 12:18: 05 PM 